AN OPEN letter from the Soviet dissident Dr Andrei Sakharov to the head of $\mathrm{KGB}, \mathrm{Mr}$ Y. V. Andropov, has just reached the West. The letter (shortened slightly in this version) reads as follows:

'On December 20, I received a letter from a mythical Russian Christian Party, which contained threats directed at my son-in-law, Efrem Yankelevich, and my one-year-old grandson.

The authors of the letter threaten to destroy them, if I continue my civic activity.

The content and whole tone of this letter make it obvious that it was composed by your officials with the aim of frightening me and forcing me to keep quiet.

The previous day I had received notification from the visa office that Yankelevich and his wife had been refused permission for a journey to the United States at the invitation of the President of the Massachusetts Institute of Technology.

Prior to this, their application had lain unanswered for a year and eight months. This coincidence cannot be accidental. I declare that the members of my family are hostages and are being used as a means of exerting pressure on me.

This has been confirmed again today. Two of your officials, who were tailing my son-in-law on the street, repeated word for word the same threats as before (adding some foul language) and demanding an end to my activity.

I demand an end to the harassment of me. I demand an end to the thuggery, and assurances of security for my family.

Don't disgrace your department even more by threatening the lives of children in the way practised in Stalin's time.

In the present circumstances, for which your department bears the responsibility, I demand that permission be granted at once to Efrem Yankelevich, his wife Tanya Semyonova and their son to travel to the US for an unlimited period, but on Soviet passports so that they will have the right to return home when their security can once again be assured.

It is quite clear that they are hostages. The only way of ending this form of pressure on me is to give them visas at once.

I also demand immediate permission for my wife to travel to Italy for treatment (for her blindness).

I demand an end to the disconnecting of my international phone calls.

I demand an end to the judicial and extra-judicial persecution of my friends, including Sergei Kovalov, who was arrested on 27 December.
At the same time as sending you this letter I am making it generally available and appealing to the world public for its suport and defence.'

Vera Rich adds:

With the enforced departure Solzhenitsyn and Medvedev, Academician Andrei Sakharov, has found himself in an increasingly exposed and lonely position as Russia's "voice of conscience". That the Soviet authorities would like to silence him was only too apparent from the vicious press campaign launched against him in September 1973. This having failed, the alternatives remaining arc exile or

\section{Dissident voices}

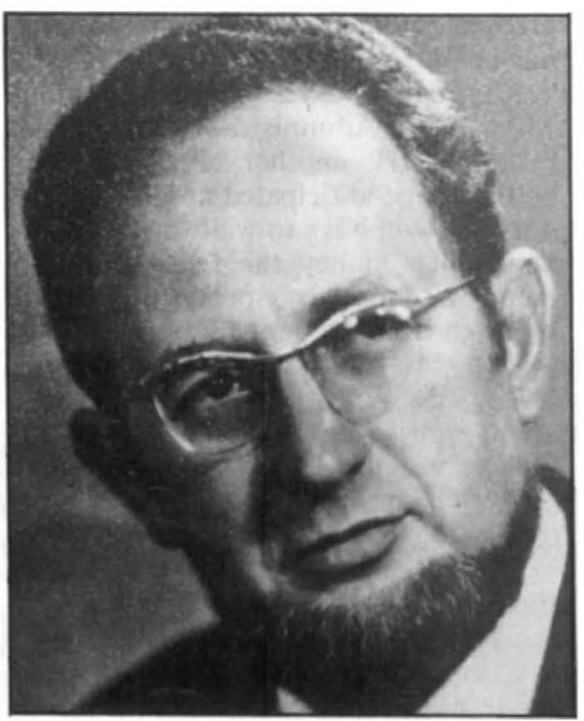

Polskii : expert refusnik physical violence-directed not at himself but at his family-his wife, stepdaughter and her husband and baby. - Physicist Viktor Polskii, who, after more than four years' delay, was finally allowed to leave the Soviet Union for Israel in December 1974, is perhaps one of the best authorities on the problems facing the "refusnik", since in his case, the customary harassment included a charge of dangerous driving, which could have carried a considerable prison sentence, but which, under the pressure of world opinion finally resulted in a fine of 100 roubles ( $£ 50$ ).

Talking to Nature this week about Jewish emigration, and, in particular, the emigration of Jewish scientists from the Soviet Union as a result of the recent rejection of the trade agreement, Polskii stressed that in fact the policy of permitting limited emigration to Israel was begun before the Soviets entered upon their course of detente and trade agreements with the USA. Emigration, or rather, the appli- cation for emigration, began on a large scale in 1970-71, long before the toplevel trade talks began. He says that the idea of limited emigration was decided at the Politbureau meetings f held in preparation for the Twentyfourth Party Congress which opened on March 26, 1971. (A large party of emigrants left on March 1st). It would seem, however, that the scalc of the applications somewhat disconcerted the Soviet authorities, resulting in the imposition for a time of the "education tax" on Jewish intellectuals wishing to emigrate, together with the policy of harassment and general unpleasantness which persists to this day.

For the future, Polskii sees the continuation of "limited" emigration, but with increasing pressure on applicants, especially intellectuals. The five cities of Moscow, Leningrad, Kiev, Khar'kov and Minsk together account for $1,000,000$ Jews-some $30 \%$ of the Jewish population of the Soviet Union, and virtually the entire Jewish intelligentsia. It is from these cities, that he expects emigration to be most difficult. Further, there is the concept of the "closed town", which has been mentioned in visa refusals - towns such as Sverdlovsk, from which, it appears, no emigration is to be permitted at all.

The current pressure on refusniksdismissal from one's job, followed by prosecution for parasitism (being without visible means of support), may well account for a certain falling off in the number of applications. Nevertheless, says Polskii, the would-be emigrants are not entirely abandoning hope. While not actually putting in a visa application at present, a great number of them are careful to keep themselves provided with an up-to-date invitation from a relative in Israel, so as to be ready to apply the moment circumstances seem slightly more propitious.

- The Russian biologist and writer Vladimir Konstantinovich Bukovskii, at present serving a twelve-year prison sentence is a result of supplying Western psychiatrists with documents on the confinement of dissidents in mental institutions is reported to be dangerously ill. Although suffering from a heart condition related to rheumatism, a liver condition, and duodenal ulcers, Bukovskii is receiving no medical attention, and medicines sent to him by his mother have been returned. $\mathrm{He}$ is unable to digest the prison diet of salt herring, spratts and cabbage. In an appeal to Minister of the Interior Sholokov, sent on January 29, Nina Bukoskaya pointed out that her son "is being slowly murdered by being deprived of medical treatment and correct medical diet". To date, no reply to her appeal has been received. 